\title{
Characterization of a $\beta$-glucanase produced by Rhizopus microsporus var. microsporus, and its potential for application in the brewing industry
} Klecius R Silveira Celestino1, Ricardo B Cunha ${ }^{2}$ and Carlos R Felix*1

\author{
Address: ${ }^{1}$ Laboratório de Enzimologia, Departamento de Biologia Celular, Universidade de Brasília, Brasília, DF, CEP 70910-900, Brazil and \\ ${ }^{2}$ Centro Brasileiro de Serviços e Pesquisas em Proteínas (LB QP)-Divisão de Química Analítica, Instituto de Química, Universidade de Brasília, \\ Brasília, DF, CEP 70910-900, Brazil \\ Email: Klecius R Silveira Celestino - klecius@unb.br; Ricardo B Cunha - rbcunha@unb.br; Carlos R Felix* - carlosrf@unb.br \\ * Corresponding author
}

Published: 05 December 2006

BMC Biochemistry 2006, 7:23 doi:10.1186/147/-2091-7-23
Received: 03 July 2006

Accepted: 05 December 2006

This article is available from: http://www.biomedcentral.com//47/-209//7/23

(c) 2006 Celestino et al; licensee BioMed Central Ltd.

This is an Open Access article distributed under the terms of the Creative Commons Attribution License (http://creativecommons.org/licenses/by/2.0), which permits unrestricted use, distribution, and reproduction in any medium, provided the original work is properly cited.

\begin{abstract}
Background: In the barley malting process, partial hydrolysis of $\beta$-glucans begins with seed germination. However, the endogenous I,3-I,4- $\beta$-glucanases are heat inactivated, and the remaining high molecular weight $\beta$-glucans may cause severe problems such as increased brewer mash viscosity and turbidity. Increased viscosity impairs pumping and filtration, resulting in lower efficiency, reduced yields of extracts, and lower filtration rates, as well as the appearance of gelatinous precipitates in the finished beer. Therefore, the use of exogenous $\beta$-glucanases to reduce the $\beta$-glucans already present in the malt barley is highly desirable.
\end{abstract}

Results: The zygomycete microfungus Rhizopus microsporus var. microsporus secreted substantial amounts of $\beta$-glucanase in liquid culture medium containing $0.5 \%$ chitin. An active protein was isolated by gel filtration and ion exchange chromatographies of the $\beta$-glucanase activity-containing culture supernatant. This isolated protein hydrolyzed I,3-I,4- $\beta$-glucan (barley $\beta$-glucan), but showed only residual activity against I,3- $\beta$-glucan (laminarin), or no activity at all against I,4- $\beta$-glucan (cellulose), indicating that the $R$. microsporus var. microsporus enzyme is a member of the EC 3.2.1.73 category. The purified protein had a molecular mass of $33.7 \mathrm{kDa}$, as determined by mass spectrometry. The optimal $\mathrm{pH}$ and temperature for hydrolysis of I,3-I,4- $\beta$-glucan were in the ranges of 4-5, and $50-60^{\circ} \mathrm{C}$, respectively. The $\mathrm{Km}$ and $\mathrm{Vmax}$ values for hydrolysis of $\beta$-glucan at $\mathrm{pH} 5.0$ and $50^{\circ} \mathrm{C}$ were $22.39 \mathrm{mg} \cdot \mathrm{mL}^{-1}$ and $16.46 \mathrm{mg} \cdot \mathrm{min}^{-1}$, respectively. The purified enzyme was highly sensitive to $\mathrm{Cu}^{+2}$, but showed less or no sensitivity to other divalent ions, and was able to reduce both the viscosity and the filtration time of a sample of brewer mash. In comparison to the values determined for the mash treated with two commercial glucanases, the relative viscosity value for the mash treated with the I,3-I,4- $\beta$-glucanase produced by $R$. microsporus var. microsporus. was determined to be consistently lower.

Conclusion: The zygomycete microfungus $R$. microsporus var. microsporus produced a I,3-1,4- $\beta$-D-glucan 4-glucanhydrolase (EC 3.2.I.73) which is able to hydrolyze $\beta$-D-glucan that contains both the I,3-and I,4bonds (barley $\beta$-glucans). Its molecular mass was $33.7 \mathrm{kDa}$. Maximum activity was detected at $\mathrm{pH}$ values in the range of $4-5$, and temperatures in the range of $50-60^{\circ} \mathrm{C}$. The enzyme was able to reduce both the viscosity of the brewer mash and the filtration time, indicating its potential value for the brewing industry. 


\section{Background}

$1,3-1,4-\beta$-Glucans are polysaccharides, components of the cell walls of higher members of the Poaceae family. They areparticularly abundant in the endosperm cell walls of commercially valuable cereals such as barley, rye, sorghum, oats and wheat [1]. Structurally, these polysaccharides are linear glucans of up to $1,200 \beta$-D-glucosyl residues linked through $\beta-1,3$ and $\beta-1,4$ glycosyl bonds. Variations in the proportions of $\beta-1,3-(25-30 \%)$ and $\beta$ 1,4-linkages, and in the length of the mixed-linked segments are currrently reported [2]. During malt production, partial hydrolysis of barley $\beta$-glucans begins with seed germination [13]. However, the endogenous 1,3-1,4$\beta$-glucanases are heat inactivated, and the remaining high molecular weight $\beta$-glucans may cause severe problems such as increased brewer mash viscosity and turbidity[14]. Increased viscosity impairs pumping and filtration, causing lower efficiency, reduced yields of extracts, and lower filtration rates, as well as the appearance of gelatinous precipitates in the finished beer [2]. Thus, both the level of glucan-hydrolysing activities achieved during germination and the amounts of their substrates, mainly 1,3-1,4$\beta$-glucan, are important factors in the production of high quality malts. Addition of exogenous 1,3-1,4- $\beta$-glucanases to the mash could therefore be an outstanding option for improving the brewing process. However, the $\beta$-glucanases currently marketed do not really meet the brewing industry's needs, mainly due to economic factors. Novel $1,3-1,4-\beta$-glucanases with uncommon features would be highly desirable. Here we report on the production, purification and partial characterization of a 1,3-1,4- $\beta$-glucanase produced by $R$. microsporus var. microsporus, considering as well its potential for use in the brewing industry.

\section{Results and Discussion Enzyme production}

A 1,3-1,4- $\beta$-glucan-degrading filamentous fungus was isolated from a malt silo in a brewery. This zygomycete microfungus was identified as Rhizopus microsporus var. microsporus by rcDNA analysis. It grew strongly in liquid medium containing chitin as the sole carbon source, and produced substantial amounts of $\beta$-glucanase activity (Figure 1 ) which was able to fully hydrolyze barley $\beta$-glucan (1,3-1,4- $\beta$-glucan). The specificity of substrate hydrolysis by this enzyme (Table 2) fully supports the assumption that it belongs to the 3.2.1.73 category. The inducible nature of $1,3-1,4-\beta$-glucanase production has already been reported for 1,3- $\beta$-glucanase from Trichoderma sp. [27]. Although cellulose and xylan were also inducers, the levels of enzyme secreted in the presence of these carbohydrates were considered smaller than the activity induced by chitin. In cultures grown under agitation $(120 \mathrm{rpm})$ at $40^{\circ} \mathrm{C}$, the enzyme activity increased from a minimum to a maximum level within $24 \mathrm{~h}$ of growth. It has been reported that several other microrganisms, including Bacillus sp. [15]Trichoderma sp. [16], Talaromyces emersonii [17], and Rhizobium sp. [2], produce $1,3-1,4-\beta$-glucanase enzymes which are currently used in the brewing industry. However, depending on the substrate ( $\beta$-glucan) used as inducer, production of the glucanases for industrial application may be very costly, to the point of being considered economically prohibitive [28]. Chitin, on the other hand, is a relatively cheap and readily available carbon source in comparison to barley $\beta$-glucan and laminarin. The ability, therefore, of $R$. microsporus var. microsporus to produce $1,3-1,4$ - $\beta$-glucanase in the presence of chitin, favors its use on an industrial scale.

\section{Enzyme Purification}

The culture supernatant of $R$. microsporus var. microsporus grown in liquid medium containing chitin was concentrated 10 -fold by ultrafiltration, using a $10 \mathrm{kDa}$ cut-off membrane. No 1,3-1,4- $\beta$-glucanase activity was found in the filtrate. Chromatography of the concentrate on a Sephacryl S-100 gel filtration column (not shown) followed by chromatography on an SP-Sepharose ion exchange column resulted in elution of two peaks of proteins (PGI and PGII) (Figure 2). While the PGI proteins were inactive, the PGII protein (fractions 22-34) showed substantial activity against $1,3-1,4-\beta$-glucan. A summary of the purification steps of the 1,3-1,4- $\beta$-glucanase produced by the R. microsporus var. microsporus is shown in table 1 . The enzyme was purified (Figure 3 ) 55.529-fold with a yield of $114.912 \%$ and a specific activity of 12.596 U.mg ${ }^{-1}$. The molecular mass of the PGII protein was 36.5 $\mathrm{kDa}$, as indicated by SDS-PAGE analysis (Figure 3 ). This value is comparable to that $(33.7 \mathrm{kDa})$ determined by

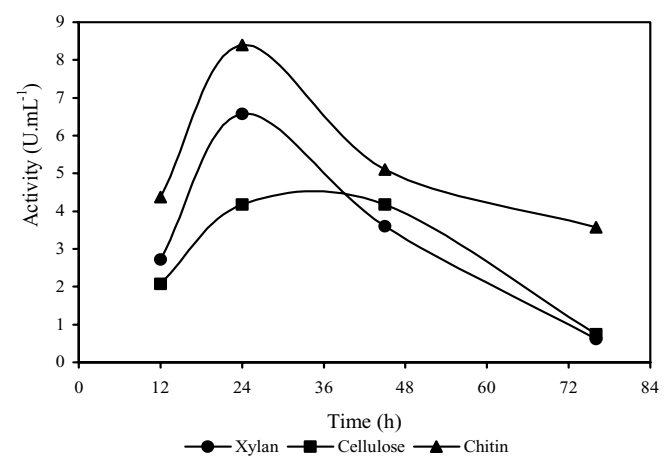

Figure 1

\section{Figure I}

Time course of production of I,3-I,4- $\beta$-glucanase by Rhizopus microsporus var. microsporus in the presence of $0.5 \%$ of either xylan, cellulose or chitin at a temperature of $40^{\circ} \mathrm{C}$ and at $120 \mathrm{rpm}$ 
Table 2: Hydrolysis of glucan substrates by the $R$. microsporus purified $\beta$-glucanase. $\Delta$ Abs $550 \mathrm{~nm}$ represents the net absorbance of the reaction mixture after incubation for $0.5 \mathrm{~h}$ with the enzyme at $50^{\circ} \mathrm{C}$.

\begin{tabular}{lc}
\hline Substrate & $\Delta$ Abs $_{550 \mathrm{~nm}}$ \\
\hline Laminarin (I,3- $\beta$-glucan) & 0.029 \\
Chitin & 0.001 \\
CM-cellulose (I,4- $\beta$-glucan) & 0.001 \\
Xylan & 0.026 \\
Manan & 0.000 \\
Barley $\beta$-glucan (I,3-I,4- $\beta$-glucan) & 0.826
\end{tabular}

mass spectrometry analysis for this enzyme (Figure 3 ). While 1,3-1,4- $\beta$-glucanases from Bacillus $s p$. have smaller molecular masses varying in the range of $25-30 \mathrm{kDa}[2]$, the enzymes from Clostridium thermocellum (38 kDa) [34], Bacteroides succinogenes (37 kDa) [33] and Talaromyces emersonii (40.7 kDa) [2] showed comparable molecular mass values.

\section{Enzyme specificity}

The R. microsporus purified $\beta$-glucanase was tested for its ability to hydrolyze several other glucan substrates. As may be seen in table 2 , only the barley $\beta$-glucan was efficiently hydrolyzed, as indicated by the much higher net absorbance. In comparison to the activity against the 1,3$1,4-\beta$-glucan, very low or no activity at all was shown by the enzyme against the substrates laminarin $(1,3-\beta$-glucan) and CM-cellulose (soluble 1,4- $\beta$-glucan), indicating clearly that the enzyme may be taken as a member of the EC 3.2.1.73 enzyme category.

\section{Effect of $\mathrm{pH}$ and temperature optima}

The effect of $\mathrm{pH}$ and temperature on the activity of the purified 1,3-1,4- $\beta$-glucanase from Rhizopus microsporus var. microsporus is shown in figures 4 and 5, respectively. At $50^{\circ} \mathrm{C}$, the enzyme showed substantial activity in the $\mathrm{pH}$ range of from 2 to 6 . Maximal activity was recorded in the range of from 4 to 5 . No enzyme activity was detected at $\mathrm{pH}$ higher than 6 (Figure 4). At pH 5.0, the purified enzyme was substantially active in the temperature range

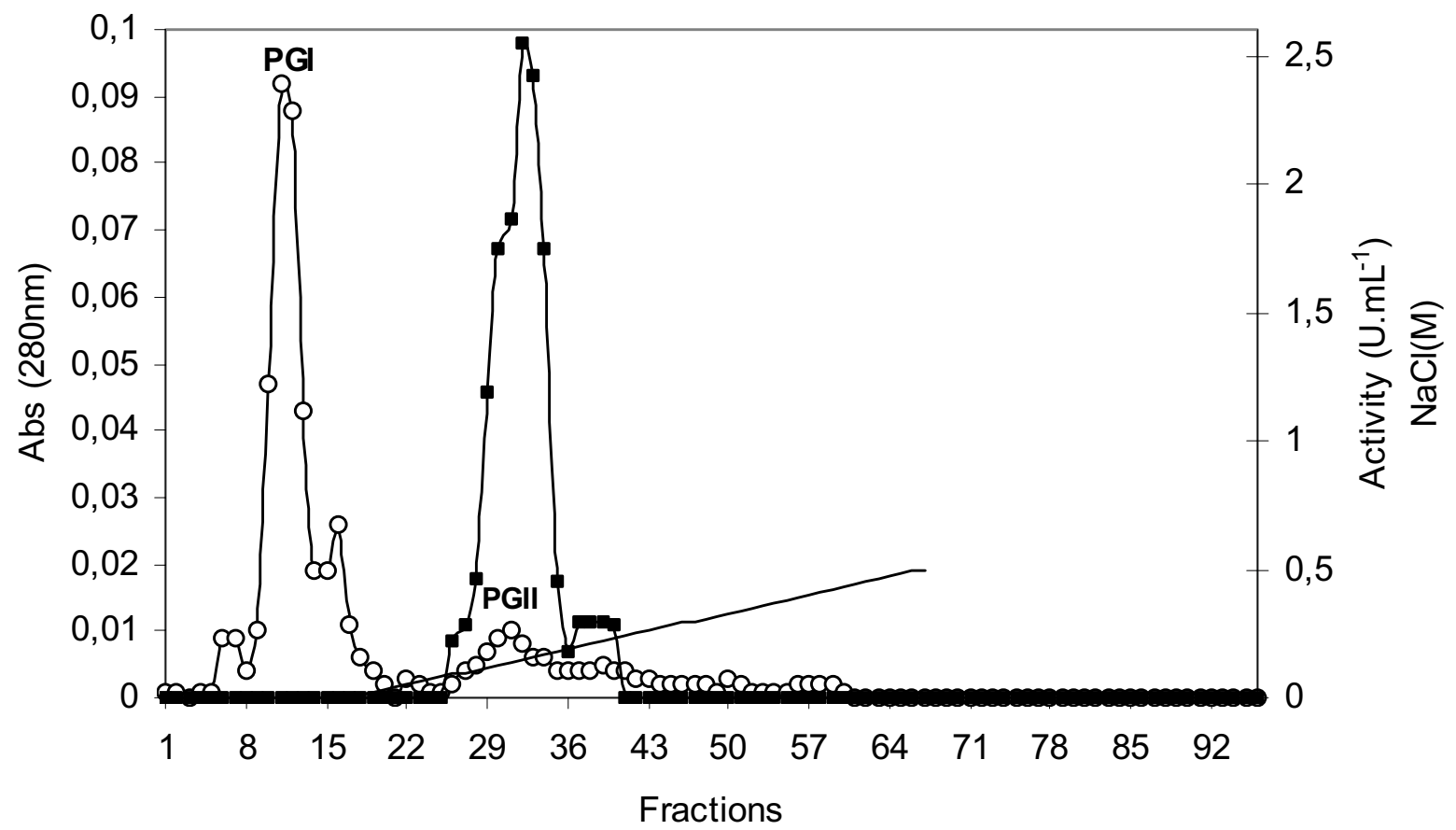

$\multimap$ Abs $(280 \mathrm{~nm}) \rightarrow$ Activity $\longrightarrow \mathrm{NaCl}(\mathrm{M})$

\section{Figure 2}

\section{Figure 2}

lon exchange (SP-Sepharose column) chromatography of the concentrated culture filtrate of Rhizopus microsporus var. microsporus grown in liquid medium containing $0.5 \%$ chitin. 




\section{Figure 3}

\section{Figure 3}

SDS-PAGE (A) and MALDI-TOF mass spectrometry (B) analysis of the purified I,3-I,4- $\beta$-glucanase from Rhizopus microsporus var. microsporus. A: line I, molecular weight markers; line 2, PGI protein fraction; line 3, PGIl protein fraction.

from $20^{\circ} \mathrm{C}$ to $65^{\circ} \mathrm{C}$. Maximal activity was detected at $50^{\circ} \mathrm{C}$ and $60^{\circ} \mathrm{C}$, indicating that the optimal temperature for glucan hydrolysis is $55^{\circ} \mathrm{C}$ (Figure 5). The optima $\mathrm{pH}$ and temperature values determined for the purified 1,3 1,4- $\beta$-glucanase from $R$. microsporus var. microsporus were similar to those determined for 1,3-1,4- $\beta$-glucanases from several other fungi and bacteria [2]. In addition, these values are comparable to those presented by enzymes currently being used in the brewing industry $[11,2]$. The purified $1,3-1,4-\beta$-glucanase retained $100 \%$ and $87 \%$ of its activity after incubation for $2 \mathrm{~h}$ and $24 \mathrm{~h}$, respectively, at $50^{\circ} \mathrm{C}$. The half-lives of the enzyme at the temperatures of $60^{\circ} \mathrm{C}$ and $70^{\circ} \mathrm{C}$ were found to be $10 \mathrm{~min}$ and $1 \mathrm{~min}$, respectively. At $50^{\circ} \mathrm{C}$, the half-life was $72 \mathrm{~h}$ (data not shown). For hydrolysis of $\beta$-glucan by a novel $1,3-1,4-\beta$ glucanase produced by Bacillus halodurans $C-125$, the $\mathrm{pH}$ optimum was between 6 and 8 , and the temperature opti- mum was $60^{\circ} \mathrm{C}$. After $2 \mathrm{~h}$ incubation at $50^{\circ} \mathrm{C}$ and $60^{\circ} \mathrm{C}$, the residual activity remained $100 \%$ and $50 \%$, respectively. The enzymatic activity was abolished after $3 \mathrm{~min}$ incubation at $70^{\circ} \mathrm{C}$. The optimum temperature for hydrolysis of lichenan by a 1,3-1,4- $\beta$-glucanase from Bacteroides succinogenes at ph 6.0 was $50^{\circ} \mathrm{C}$ [33].

\section{Effect of metal ions}

The effect of several ions on the activity of the purified 1,3$1,4-\beta$-glucanase produced by $R$. microsporus var. microsporus is shown in Table 3. The enzyme was sensitive to copper and fairly sensitive to zinc and manganese, but insensitive to magnesium, calcium and aluminum (Table 3). Glucanases produced by Rhizopus oryzae [29], Bacillus clausii [30], Bacillus halodurans [32] and Trichoderma harzianum [31] show similar sensitivity to the divalent metal ion copper.

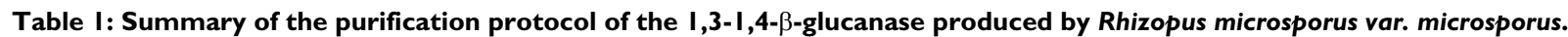

\begin{tabular}{|c|c|c|c|c|c|}
\hline Steps & Total Protein(mg) & Total Activity(U) & Specific activity(U.mg-1) & Purification (-fold) & Yield(\%) \\
\hline Concentrated crude extract & 1.574 & 0.228 & 0.197 & I & 100.000 \\
\hline Sephacryl S-100 eluate & 0.235 & 0.227 & 0.966 & 4.915 & 99.561 \\
\hline SP-Sepharose eluate & 0.021 & 0.262 & 12.596 & 55.529 & 114.912 \\
\hline
\end{tabular}




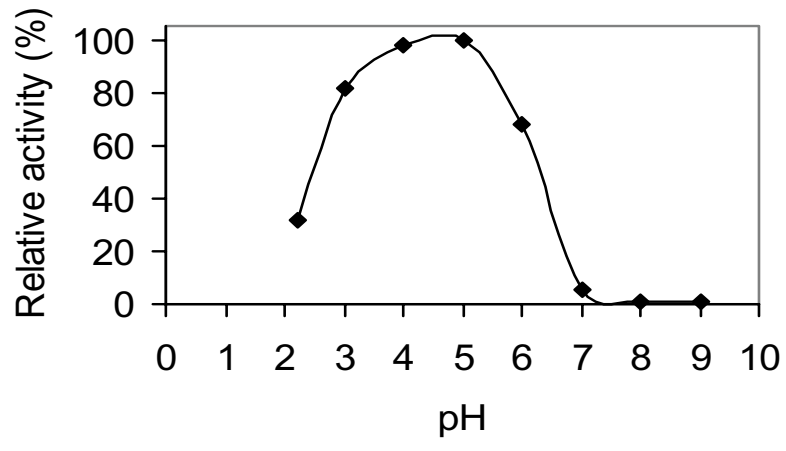

Figure 4

\section{Figure 4}

Effect of $\mathrm{pH}$ on the activity of the purified I,3-I,4- $\beta$-glucanase from Rhizopus microsporus var. microsporus, at $50^{\circ} \mathrm{C}$.

\section{Kinetic Parameters}

The purified 1,3-1,4- $\beta$-glucanase produced by $R$. microsporus var. microsporus hydrolyzed $1,3-1,4$ - $\beta$-glucan in a Michaelis-Menten fashion (Figure 7). Kinetic parameters were calculated using a Michaelis-Menten plot with a nonlinear regression data analysis program [10]. Values of $19.8 \mathrm{mg} . \mathrm{mL}^{-1}, 12.7 \mathrm{~s}^{-1}$ and 16.5 U. $\mathrm{mL}^{-1}$ were determined for $\mathrm{Km}$, Kcat and Vmax, respectively. Km values of 1.2 $1.5 \mathrm{mg} \cdot \mathrm{mL}^{-1}$ for hydrolysis of barley $\beta$-glucan and $0.8-2$ mg.mL $L^{-1}$ for lichenan were reported for the $1,3-1,4-\beta$-glucanase produced by Bacillus sp [2]. Values of 1,296 \pm 51 , $2.50 \pm 0.09$, and 518 were reported for Kcat $\left(\mathrm{s}^{-1}\right), \mathrm{Km}$ $\left(\mathrm{mg} \cdot \mathrm{mL}^{-1}\right)$ and Kcat/Km $\left(\mathrm{s}^{-1} \cdot \mathrm{M}^{-1}\right)$ respectively, for hydrolysis of lichenan by a 1,3-1,4- $\beta$-glucanase produced by Bacteroides succinogenes. [33].

\section{Capillary Viscosimetry and Filtration rate}

The specific filtration rate and specific viscosity rate of the mash after incubation with the 1,3-1,4- $\beta$-glucanase from

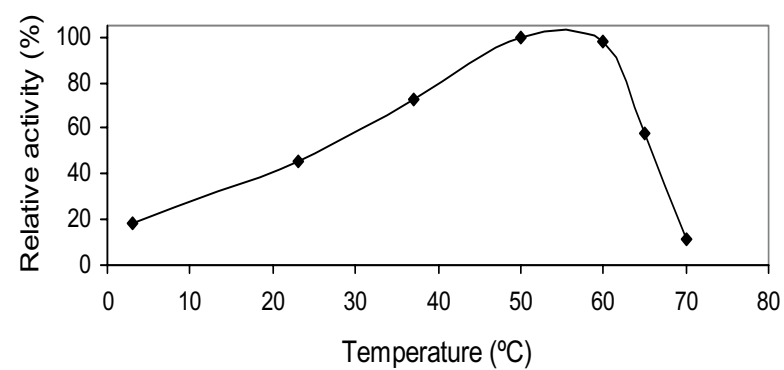

Figure 5

Figure 5

Effect of temperature on the activity of the purified I,3-I,4- $\beta$ glucanase from Rhizopus microsporus var. microsporus, at $\mathrm{pH}$ 5.0.
Table 3: Effect of metal ions on the activity of the purified I,3I,4- $\beta$-glucanase from Rhizopus microsporus var. microsporus.

\begin{tabular}{lc}
\hline Ion & Residual activity (\%) \\
\hline Control & 100 \\
$\mathrm{Cu}^{+2}(12 \mathrm{mM})$ & 0.3 \\
$\mathrm{Mg}^{+2}(12 \mathrm{mM})$ & 95.2 \\
$\mathrm{Fe}^{+3}(12 \mathrm{mM})$ & 89.6 \\
$\mathrm{Zn}^{+2}(12 \mathrm{mM})$ & 65.0 \\
$\mathrm{Mn}^{+2}(12 \mathrm{mM})$ & 62.3 \\
$\mathrm{Ca}^{+2}(12 \mathrm{mM})$ & 105.9 \\
$\mathrm{Al}^{+3}(12 \mathrm{mM})$ & 109.8
\end{tabular}

R. microsporus var microsporus were compared with those values calculated for two commercial $\beta$-glucanases currently used in the brewing industry. The results are shown in Tables 4 and 5. Even at lower enzyme concentration, the 1,3-1,4- $\beta$-glucanase from $R$. microsporus var microsporus caused a higher reduction in the filtration rate $(20.4 \%)$ of the mash (table 4). Similar results were obtained for the specific viscosity of the brewer's mash after treatment with the three $\beta$-glucanases (table 5).

\section{Conclusion}

The zygomycete Rhizopus microsporus var. microsporus produced a 1,3-1,4- $\beta$-D-glucan 4-glucanhydrolase (EC 3.2.1.73) which could hydrolyze $\beta$-D-glucan substrate containing both 1,3- and 1,4-bonds. Its molecular mass as determined by both electrophoresis and mass spectrometry (MALDI-TOF) was about $33.7 \mathrm{kDa}$. Its optimum $\mathrm{pH}$ and temperature were found to be in the ranges of 4-5 and $50-60^{\circ} \mathrm{C}$, respectively. Kinetic analysis and its capacity to reduce both the viscosity of the brewer mash and the

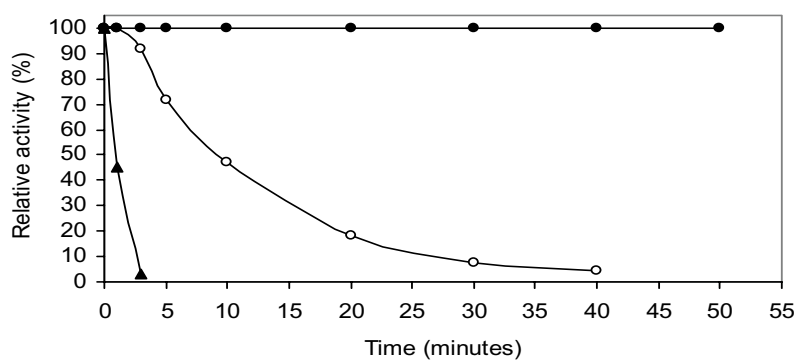

Figure 6

Figure 6

Thermostability of the purified I,3-I,4- $\beta$-glucanase from Rhizopus microsporus var. microsporus, at temperatures of $50^{\circ} \mathrm{C}$ (O), $60^{\circ} \mathrm{C}(\mathrm{O})$ and $70^{\circ} \mathrm{C}(\boldsymbol{\Delta})$, at $\mathrm{pH} 5.0$. 


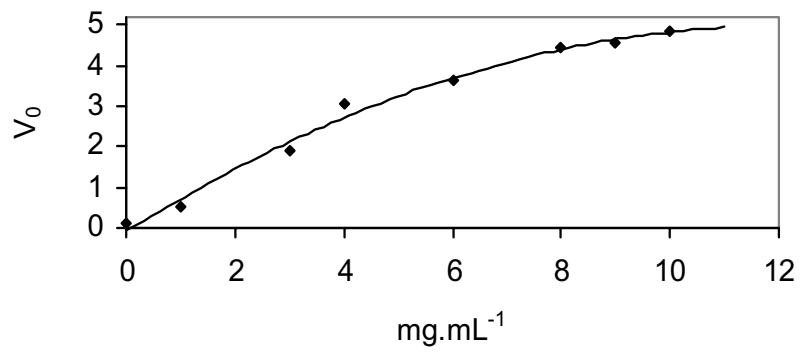

Figure 7

\section{Figure 7}

Hydrolysis $\left(\mu \mathrm{mol} \cdot \mathrm{min}^{-1} \cdot \mathrm{mL}^{-1}\right)$ of $\beta$-glucan by the purified I,3I,4- $\beta$-glucanase from Rhizopus microsporus var. microsporus, in the presence of different concentrations of I,3-I,4- $\beta$-glucan.

filtration time, indicate the possibility to use this enzyme in the brewing industry.

\section{Methods}

\section{Chemicals}

Barley 1,3-1,4- $\beta$-glucan, chitin, CM-cellulose, manan, xylan, laminarin, molecular mass standard proteins and sodium dodecyl sulfate (SDS) were from Sigma Chemical Co., USA. Sephacryl S-100 and SP-Sepharose were from Pharmacia-LKT, Sweden. All other chemicals were of analytical grade.

\section{Organism and enzyme production}

The aerobic zygomycete microfungus Rhizopus microsporus var. microsporus was isolated from a malt silo. The fungus was maintained at $4{ }^{\circ} \mathrm{C}$, after growing for 48 hours in TLE modified solid medium [ $0.5 \%$ chitin, $0.2 \% \mathrm{KH}_{2} \mathrm{PO}_{4}$, $0.14 \%\left(\mathrm{NH}_{4}\right)_{2} \mathrm{SO}_{4}, 0.03 \% \mathrm{MgSO}_{4} .7 \mathrm{H}_{2} \mathrm{O}, 0.0152 \% \mathrm{CaCl}_{2}$, $0.02 \%$ glucose, $1.0 \mathrm{~mL}$ of $0.01 \%$ trace elements solutions $\left(\mathrm{Fe}^{+2}, \mathrm{Mn}^{+2}, \mathrm{Zn}^{+2}, \mathrm{Co}^{+2}\right), 0.003 \%$ bactopeptone, $0.003 \%$ urea, and $2 \%$ agar, $\mathrm{pH} 6.8)]$, at $40^{\circ} \mathrm{C}$.

For enzyme production, one liter Erlemeyer flasks containing $250 \mathrm{~mL}$ of the liquid medium (TLE with no agar), were inoculated with $150 \mathrm{~cm}^{2}$ blocks of solid medium taken from 2-day old R. microsporus var. microsporus cultures. Liquid cultures were then incubated for 24 hours with agitation $(120 \mathrm{rpm})$ at $40^{\circ} \mathrm{C}$. The culture supernatants were then separated from the mycelium by filtration, using filter paper. The supernatants were then freeze-dried and used either for enzyme assay or enzyme purification as described in the following sections.

\section{Enzyme assay}

$1,3-1,4-\beta$-glucanase activity was assayed by the reducingsugar method [6] with $\beta-1,3-\beta-1,4$-glucan as the substrate. The assay system consisted of $50 \mu \mathrm{L}$ of $1 \%$ (wt/vol) $\beta$-glucan dissolved in $100 \mathrm{mM}$ sodium acetate buffer, $\mathrm{pH}$ 5.0, and $50 \mu \mathrm{L}$ enzyme sample. The reaction was allowed to proceed for $30 \mathrm{~min}$ at $50^{\circ} \mathrm{C}$, and was then stopped by the addition of $300 \mu \mathrm{L}$ dinitrosalicylate reagent [6], and $5 \mathrm{~min}$ of boiling. The absorbance of the reaction mixture was determined at $550 \mathrm{~nm}$ using a Perkin Elmer mod. Lambda 11/Bio spectrophotometer. The amount of reducing sugar produced was determined using a curve constructed with glucose as standard. One unit of enzyme was defined as the amount of protein necessary to produce one $\mu \mathrm{mol}$ of reducing sugars. $\mathrm{min}^{-1}$.

The assays for xylanase, cellulase, 1,3- $\beta$-glucanase and mananase were performed as for 1,3-1,4- $\beta$-glucanase, except for the use of the substrates carboximetilcellulose, laminarin and manan, respectively. For chitinase the enzyme system consisted of $100 \mu \mathrm{L}$ of enzyme sample, regenerated chitin $0,5 \%$ in $50 \mathrm{mM}$ sodium acetate buffer, $\mathrm{pH} 5.2$ [35]. The reaction was allowed to run for $12 \mathrm{~h}$ at $37^{\circ} \mathrm{C}$ and stopped by addition of dinitrosalycilic reagent. The amount of reducing sugar produced was quantified using a standard curve constructed with glucose.

\section{Purifications of the I,3-I,4- $\beta$-glucanase from Rhizopus microsporus var. microsporus}

The supernatants from cultures of $R$. microsporus var. microsporus grown in liquid medium containing $\beta$-glucan were concentrated by ultrafiltration [(Amicon system; 10 $\mathrm{k}$-Da cut-off membrane (PM10)]. Aliquots of concentrated $\beta$-glucanase were loaded on a Sephacryl S-100 gel column $(2.5 \times 40 \mathrm{~cm})$, equilibrated and eluted with 50 $\mathrm{mM}$ sodium acetate buffer, $\mathrm{pH}$ 5.0. Elution was per-

Table 4: Total protein in the enzyme samples, filtration time, filtration time reduction and specific filtration time reduction of the brewer's mash not treated or treated with enzymes.

\begin{tabular}{lcccc}
\hline & $\begin{array}{c}\text { Total Protein in the } \\
\text { enzyme sample }(\mu \mathrm{g})\end{array}$ & $\begin{array}{c}\text { Filtration time } \\
(\mathbf{s e c o n d s )}\end{array}$ & $\begin{array}{c}\text { Filtration time } \\
\text { reduction }(\%)\end{array}$ & $\begin{array}{c}\text { Specific filtration time } \\
\text { reduction }(\% / \mu \mathrm{g})\end{array}$ \\
\hline $\begin{array}{l}\text { Control } \\
\begin{array}{l}\text { R. microsporus var } \\
\text { microsporus enzyme }\end{array}\end{array}$ & - & 274 & - & - \\
$\begin{array}{l}\text { Commercial enzyme A } \\
\text { Commercial enzyme B }\end{array}$ & 11.0 & 218 & 20.4 & $1854.5 \times 10^{-3}$ \\
\end{tabular}


Table 5: Total protein in the enzyme samples, viscosity, viscosity reduction and specific viscosity reduction of the brewer's mash not treated or treated with enzymes.

\begin{tabular}{lcccc}
\hline & $\begin{array}{c}\text { Total Protein in the } \\
\text { enzyme sample }(\mu \mathrm{g})\end{array}$ & Viscosity (cP) & Viscosity reduction (\%) & $\begin{array}{c}\text { Specific viscosity } \\
\text { reduction }(\% / \mu \mathrm{g})\end{array}$ \\
\hline $\begin{array}{l}\text { Control } \\
\begin{array}{l}\text { R. microsporus var } \\
\text { microsporus enzyme }\end{array}\end{array}$ & - & 1.070 & - & - \\
$\begin{array}{l}\text { Commercial enzyme A } \\
\text { Commercial enzyme B }\end{array}$ & 110 & 1.020 & 4.7 & $763 \times 10^{-3}$ \\
\hline
\end{tabular}

formed at a flow rate of $24 \mathrm{~mL} \cdot \mathrm{h}^{-1}$, and fractions of $4.0 \mathrm{~mL}$ were collected. Active fractions were pooled and applied on a SP-Sepharose ion-exchange column $(3.0 \times 15 \mathrm{~cm})$, previously equilibrated and eluted with $50 \mathrm{mM}$ sodium acetate buffer, $\mathrm{pH}$ 5.0, and further eluted with a linear gradient formed with $100 \mathrm{~mL}$ of the acetate buffer and 100 $\mathrm{mL}$ of the same buffer containing $1 \mathrm{M} \mathrm{NaCl}$. Elution was carried out at a flow rate of $24 \mathrm{~mL} \cdot \mathrm{h}^{-1}$, and fractions of 4 $\mathrm{mL}$ were collected. The resulting active fractions were pooled and dialyzed overnight against distilled water at $4^{\circ} \mathrm{C}$, concentrated by ultrafiltration as above, and stored at $-20^{\circ} \mathrm{C}$ until their use.

\section{Protein determination}

Protein was determined by the Bradford method [7], with bovine serum albumin as standard.

\section{Electrophoresis}

Enzyme samples were examined by electrophoresis under denaturing conditions in polyacrylamide slab gels (SDSPAGE) as described by Laemmli [8]. Protein bands in the gel were visualized by the silver staining method [9].

\section{Mass spectrometry}

$1,3-1,4-\beta$-glucanase was analyzed by matrix-assisted laser desorption ionization-time of flight (MALDI-TOF) mass spectrometry with a Reflex IV mass spectrometer (Bruker Daltonik, Bremen, Germany) in linear positive mode. The purified enzyme sample $(50 \mu \mathrm{g})$ was dissolved in $50 \mu \mathrm{L}$ of $0.1 \%(\mathrm{v} / \mathrm{v}) \mathrm{TFA}$, from which $1 \mu \mathrm{L}$ was mixed with $1 \mu \mathrm{L}$ of a saturated matrix solution of sinapinic acid dissolved in $50 \%(\mathrm{v} / \mathrm{v})$ acetonitrile and $0.1 \%(\mathrm{v} / \mathrm{v})$ trifluoroacetic acid, and applied to the MALDI plate. BSA was used for external mass calibration.

\section{Effects of ions}

The effects of several metallic ions $\left(\mathrm{Cu}^{+2}, \mathrm{Mg}^{+2}, \mathrm{Fe}^{+3}, \mathrm{Zn}^{+2}\right.$, $\mathrm{Ca}^{+2}$, and $\mathrm{Al}^{+3}$ ) on the purified 1,3-1,4- $\beta$-glucanase were tested measuring the activity of the enzyme at $50^{\circ} \mathrm{C}$ (see $1,3-1,4-\beta$-glucanase assay) in the presence of the ions.

\section{pH and temperature optima}

The effect of temperature on the enzyme was carried out at the temperature range of from $4^{\circ}$ to $70^{\circ} \mathrm{C}$, at pH 5.0 (in $50 \mathrm{mM}$ sodium acetate buffer). The optimum $\mathrm{pH}$ value was determined by monitoring the enzyme activity at $50^{\circ} \mathrm{C}$ at $\mathrm{pH}$ values from 3.0 to 9.0. The following buffers were used: $\mathrm{pH} 3.0$ - 6.0, $50 \mathrm{mM}$ sodium acetate; $\mathrm{pH} 7.0$, $50 \mathrm{mM}$ sodium phosphate; and $\mathrm{pH} 8.0$ - 9.0, $50 \mathrm{mM}$ tris$\mathrm{HCl}$.

\section{Kinetic Parameters}

For determination of kinetic parameters, the enzyme assays were performed at $50^{\circ} \mathrm{C}$, using $1,3-1,4$ - $\beta$-glucan at concentrations varying from 0.05 to $2.0 \%$ dissolved in 50 $\mathrm{mM}$ sodium acetate buffer, $\mathrm{pH}$ 5.0. Km, Kcat and Vmax values were obtained using a Michaelis-Menten plot with a non-linear regression data analysis program [10].

\section{Preparation of the mash}

$12.5 \mathrm{~g}$ of malt was triturated in a hammer mill (MAROTEC), drizzled into a sieve of $0.2 \mathrm{~mm}$ spacing, and dissolved in $50 \mathrm{~mL}$ of sodium acetate buffer $(100 \mathrm{mM}, \mathrm{pH}$ $5.5)$, pre-heated to $45^{\circ} \mathrm{C}$. Reaction started with $1.0 \mathrm{~mL}$ of enzyme sample taken from chromatography on a Sephacryl S-100 column, and allowed to proceed for 30 min at $45^{\circ} \mathrm{C}$, followed by other periods of $10 \mathrm{~min}$ at $50^{\circ} \mathrm{C}, 15 \mathrm{~min}$ at $60^{\circ} \mathrm{C}, 60 \mathrm{~min}$ at $70^{\circ} \mathrm{C}$, and $5 \mathrm{~min}$ of boiling. The reaction was then stopped by the addition of 100 $\mathrm{mL}$ of cold water and immediate cooling in an ice-water bath at about $20^{\circ} \mathrm{C}$.

\section{Capillary viscosimetry}

Decrease in mash viscosity was measured by capillary viscosimetry using an Oswald viscosimeter $[12,20]$. Samples of $30 \mathrm{~mL}$ of mash were filtered using filter paper and placed in a viscosimeter at $20^{\circ} \mathrm{C}$. Mash viscosity in the absence of enzyme was used as a control. The specific viscosity rate was calculated using the following equations:

$\mu_{\text {mash }}=\left(\mu_{\text {water }} \times \mathrm{T}_{\text {mash }} \times \rho_{\text {mash }}\right) /\left(\mathrm{T}_{\text {water }} \times \rho_{\text {water }}\right)$ 
$\Delta \mu=\left(\mu_{\text {mash control }}-\mu_{\text {mash }}\right) \times 100 /\left(\mu_{\text {mash control }}\right)$

$\Delta \mu \phi=\Delta \mu / \delta$

Where $\mu$ is the viscosity, $\mathrm{T}$ is the flow time, $\Delta \mu$ is viscosity reduction, $\delta$ is total protein, $\Delta \mu \phi$ is specific viscosity rate and $\rho$ is the density.

\section{Filtration rate}

The filtration rate was determined by filtration of $50 \mathrm{~mL}$ of mash through a filter paper [12]. Filtration rate in the absence of enzyme was used as a control. The specific filtration rate was calculated using the following equations:

$\Delta_{\psi}=\left(\psi_{\text {mash control }}-\psi_{\text {mash }}\right) \times 100 /\left(\psi_{\text {mash control }}\right)$

$\Delta_{\psi \phi}=\Delta \psi / \delta$

Where $\psi$ is the flow time, $\Delta \psi$ is the filtration time of 50 $\mathrm{mL}, \delta$ is total protein and $\Delta \psi \phi$ is the specific filtration reduction.

\section{Authors' contributions}

KRSC conceived of the study and participated in its design, performed all experiments, data quantification and was involved in the literature search and data interpretation. RBC participated and supported the mass spectrometry analysis with a Reflex IV mass spectrometer. CRF participated in the design and coordination of the study, as well as on its supervision, and helped to draft the manuscript. All authors read and approved the final manuscript.

\section{Acknowledgements}

CRF acknowledge the scholarship awarded by CNPq (process: 305 I23/ 2005-0).

\section{References}

I. Stone BA, Clarke AE: Chemistry and Biology of I,3- $\beta$-Glucans. Bundoora: La Trobe University Press;; 1992.

2. Planas A: Bacterial I,3-I,4- $\beta$-glucanases: structure, function and protein engineering. Biochimica et Biophysica Acta 2000, I 543:36 |-382

3. Bamforth $\mathrm{CW}: \beta$-Glucan and $\beta$-glucanases in malting and brewing: practical aspects. Brewers Digest 1994, 69:12-16.

4. Fincher GB, Stone BA: Advances in cereal science and technology. Volume 7. American Association of Cereal Chemists. St. Paul; 1986.

5. Godfrey T, West S: Industrial enzymology. New York : Stockton Press; 1996.

6. Miller GL: Use of dinitrosalycilic acid reagent for determination of reducing sugar. Analytical Chemistry 1959, 3 I:426-428.

7. Bradford MM: A rapid and sensitive method for the quantitation of microgram quantities of protein utilizing the principle of protein dye binding. Analitical Biochemical 1976, 72:248-254.

8. Laemmli UK: Cleavage of structural proteins during assembly of head of bacteriophage-T4. Nature 1970, 227:680-685.

9. Blum H, Beier H, Gross B: Improved silver staining of plant proteins, RNA and DNA in polyacrilamide gels. Electrophoresis 1987, 8:93-99.

10. Leatherbarrow RJ: Enzifitter: a non-linear regression data analysis program for the IBM PC. London: Biosoft; 1987:1-91.
II. McCleary BV, Nurthen E: Measurement of (I-3)(I-4)- $\beta$-D-glucan in malt, wort and beer. Journal of the Institute of Brewing 1986, 92:168-173.

12. McCleary BV, Shameer I, Glennieholmes M: Measurement of (I3),(I-4)- $\beta$-D-glucan. Methods in Enzymology 1988, 160:545-55I.

13. Kettunen A, Hamalainen JJ, Stenholm K, Pietila K: A model for the prediction of $\beta$-glucanase activity and beta-glucan concentration during mashing. Journal of Food Engineering 1996, 29:185-200.

14. Bamforth $\mathrm{CW}$, Martin HL: The degradation of $\beta$-glucan during malting and mashing - the role of $\beta$-glucanase. Journal of the Institute of Brewing 1983, 89:303-307.

15. McCarthy T, Hanniffy O, Lalor E, Savage AV, Tuohy MG: Evaluation of three thermostable fungal endo- $\beta$-glucanases from Talaromyces emersonii for brewing and food applications. Process Biochemistry 2005, 40:1741-1748.

16. Bhat MK: Cellulases and related enzymes in biotechnology. Biotechnology Advances 2000, 18:355-383.

17. Jayus, McDougall BM, Seviour RJ: Purification and characterization of the (I>3)- $\beta$-glucanases from Acremonium sp IMI 383068. FEMS Microbiology Letters 2004, 230:259-264.

18. Scheffler A, Bamforth CW: Exogenous $\beta$-glucanases and pentosanases and their impact on mashing. Enzymes and Microbial Technology 2005, 36:8I3-817.

19. Murray PG, Grassick A, Laffey CD, Cuffe MM, Higgins T, Savage AV, Planas A, Tuohy MG: Isolation and characterization of a thermostable endo- $\beta$-glucanase active on I,3-I,4- $\beta$-D-glucans from the aerobic fungus Talaromyces emersonii CBS 814.70 . Enzyme and Microbial Technology 200I, 29:90-98.

20. Vlasenko EY, Ryan Al, Shoemaker CF, Shoemaker SP: The use of capillary viscometry, reducing end-group analysis, and size exclusion chromatography combined with multi-angle laser light scattering to characterize endo-I,4- $\beta$-D-glucanases on carboxymethylcellulose : A comparative evaluation of the three methods. Enzyme amd Microbial Technology 1998, 23:350-359.

2I. Gan Q, Howell JA, Field RW, England R, Bird MR, O'Shaughnessy CL, MeKechinie MT: Beer clarification by microfiltration - product quality control and fractionation of particles and macromolecules. Journal of Membrane Science 200I, 194:185-196.

22. Wang JM, Zhang GP, Chen JX, Wu FB: The changes of $\beta$-glucan content and $\beta$-glucanase activity in barley before and after malting and their relationships to malt qualities. Food Chemistry 2004, 86:223-228.

23. Wen TN, Chen JL, Lee SH, Yang NS, Shyur LF: A Truncated Fibrobacter succinogenes I,3-I,4- $\beta$-D-Glucanase with Improved Enzymatic Activity and Thermotolerance. Fibrobacter succinogenes 2005, 44:9197-9205.

24. Lusk LT, Duncombe GR, Kay SB, Navarro A, Ryder D: Barley $\beta$-glucan and beer foam stability. Journal of the American Society of Brewing Chemists 200I, 59:183-186.

25. Edney MJ, LaBerge DE, Langrell DE: Relationships among the $\beta$ glucan contents of barley, malt, malt congress extract, and beer. Journal of the American Society of Brewing Chemists 1998, 56:164-168

26. Almin KE, Eriksson KE: Enzymic degradation of polymers .I. viscometric method for determination of enzymic activity. Biochimica Et Biophysica ACTA 1967, 139:238-248.

27. Lima LHC, Ulhoa C], Fernandes AP, Felix CR: Purification of a chitinase from Trichoderma sp. and its action on Sclerotium rolfsii and Rhizoctonia solani cell walls. Journal of General and Applied Microbiology 1997, 43:31-37.

28. McCarthy TC, Lalor E, Hanniffy O, Savage AV, Tuohy MG: Comparison of wild-type and UV-mutant beta-glucanase-producing strains of Talaromyces emersonii with potential in brewing applications. Journal of Industrial Microbiology \& Biotechnology 2005, 32:125-134.

29. Murashima K, Nishimura T, Nakamura Y, Koga J, Moriya T, Sumida N, Yaguchi T, Kono T: Purification and characterization of new endo-I,4- $\beta$-D-glucanases from Rhizopus oryzae. Enzyme and Microbial Technology 2002, 30:319-326.

30. Miyanishi N, Hamada N, Kobayashi T, Imada C, Watanabe E: Purification and characterization of a novel extracellular $\beta-1,3-$ glucanase produced by Bacillus clausii NM-I isolated from ezo abalone Haliotis discus hannai. Journal of Bioscience and Bioengineering 2003, 95:45-5I. 
31. Rana DS, Theodore K, Naidu GSN, Panda T: Stability and kinetics of $\beta$-I,3-glucanse from Trichoderma harzianum. Process Biochemistry 2003, 39:149-155.

32. Akita M, Kayatama K, Hatada $Y$, Ito $S$, Horikoshi $K$ : A novel $\beta$-glucanase gene from Bacillus halodurans C-I25. FEMS Microbiology Letters 2005, 248:9-15.

33. Erfle JD, Teather RM, Wood PJ, Irvin JE: Purification and properties of a I,3-I,4- $\beta$-D-glucanase (lichenase, I,3-I,4- $\beta$-D-glucan 4-glucanohydrolase, EC-3.2.1.73) from Bacteroides succinogenes cloned in Escherichia coli. Biochemical Journal 1988, 255:833-84I.

34. Schimming S, Schawarz WH, Staudenbauer WL: Properties of a thermoactive $\beta$-I,3-I,4-glucanase (lichenase) from Clostridium thermocellum expressed in Escherichia coli. Biochemical and Biophysical Research Communications 1991, 177:447-452.

35. Molano J, Duram A, Cabib E: A rapid and sensitive assay for chitinase using tritiated chitin. Anal Biochem 1977, 83:648-656.

Publish with Bio Med Central and every scientist can read your work free of charge

"BioMed Central will be the most significant development for disseminating the results of biomedical research in our lifetime. "

Sir Paul Nurse, Cancer Research UK

Your research papers will be:

- available free of charge to the entire biomedical community

- peer reviewed and published immediately upon acceptance

- cited in PubMed and archived on PubMed Central

- yours - you keep the copyright

Submit your manuscript here:

http://www.biomedcentral.com/info/publishing_adv.asp 